\title{
Advancing Electronic Waste Management Techniques among Electrical/Electronic Technicians' Workshops for Sustainable Healthy Society
}

\author{
Ogbuanya Theresa Chinyere and Yekinni Sunkanmi Afeez* \\ Department of Industrial Technical Education, University of Nigeria, Nsukka, Nigeria
}

Submission: July 27, 2019; Published: November 19, 2019

*Corresponding author: Yekinni Sunkanmi Afeez, Department of Industrial Technical Education, University of Nigeria, Nsukka, Nigeria

\begin{abstract}
This study focused on the advancement of e-waste techniques among electrical/electronic technicians' workshops for sustainable healthy society. Study was conducted in Nigeria. The participants for the study included 87 university engineering lecturers and 54 public health officers. Study adopted survey research design and structured questionnaire for data collection. The study was validated by three experts and reliability coefficient of 0.79 was achieved. Data obtained was analyzed using percentage, mean and standard deviation while t-test and ANOVA were used to test hypotheses. The result claimed that all e-waste components are hazardous except aluminum. Meanwhile, the level of hazardous varies and depends on type of e-waste and level of abundance. Result claimed that e-waste in electrical/electronic technician workshop have severe consequences such as uncontrolled fire and inflammatory/respiratory problem among others in the environment. Result confirmed that electrical/electronic technicians adopted unsafe method for managing e-waste such as dumping of e-waste inside flowing water and swamp and using e-waste for land filling. Result explained further that electrical/electronic technicians are facing challenges- exposure to injury and unavailability of modern equipment among others- in managing e-waste. Also, result confirmed that technique for managing e-waste in electrical/electronic workshop include establishment of recycling site and establishment and implementation of regulation. Meanwhile, result stated that qualification, experience, age and occupation affects respondent opinions in response to research questions.
\end{abstract}

Keywords: Electrical/Electronic Technicians; Electrical/Electronic Workshops; E-Waste; Hazardous Component of E-Waste Material; E-Waste Management

\section{Introduction}

Educators and sociologists often conceive technicians as junior professional workers who know some proper subset of what professionals such as engineers or scientists know [1-3]. Technicians are workers in the field of technology who are proficient in relevant skills and techniques, with relatively practical understanding of theoretical principles for the purpose of carrying out installation, maintenance and repair activities $[4,5]$. Engineering technicians are charged with responsibilities like testing, monitoring, identifying, correcting and repairing (troubleshooting) problem that may arise on devices [6,7]. Generally, the ultimate function, discipline and way of life of technicians is to troubleshoot and ensure that machines and other physical systems remain in good working order [8]. Meanwhile, during the 1950s and 1960s, technician was routinely cross-referenced with "radio and television" as well as "electronics" repair [9]. This marks the beginning of electrical/electronic technicians.

\section{Electrical/Electronic Technicians}

Seigler [10] opined that electrical/electronic technician is a person working on electrical/electronic equipment at technical level between the skilled tradesman and the professional electrical engineer/scientists who has the technical knowledge and skill necessary to repair and service the modern-day consumer electronic products. In Nigeria, electrical/electronic technicians are trained in technical colleges to acquire necessary skills and competencies to carryout maintenance and repair activities such as dismantling, assembling, repairing, servicing, maintaining and installing electrical/electronic equipment and home appliances [11-14]. Arthur, et al. [1]; Seigler [10]; Dearden [15]; Bureau of Labour Statistics [16], Onuoha [17] reported that aside from upholding the responsibility of training apprentices, electrical/electronic technicians are charged to advice consumers, plan, design, develop, construct, assemble, erect, install, maintain, repair, adjust, monitor, service, test and commission elec- 
trical equipment/appliances. Seigler [10] asserted that most of electrical/electronic technicians carry out their function and maintenance activities in service shops or in stores popularly termed as workshop - a place where technicians and learners/ apprentices experiment, test, construct, dismantle, repair, design, create, imagine and study [18-20]. Electrical/Electronic technicians troubleshoot, maintain and repair appliances and equipment of different types such as refrigerator and air-conditions, electric motors and generators, voltage regulators, electric fan, Radio and Television sets, Amplifiers and Video recorders among others $[11,13]$. To be candid, the work of electrical/electronic technicians are acknowledged, recognized and supported globally. Experts expatiated that manufacturers of electrical/ electronic appliances are providing supportive skill training to technicians which enable technicians of electrical/electronic appliances to carry out repairing and maintenance activities to take faulty equipment back to their normal working condition for economic concern [21-24].

Meanwhile, ageing, shorter life span, emergence of new and latest technology, obsoleteness of existing technology, scarcity of spare parts to rectify faulty equipment, poor technological knowhow behind electrical/electronic product among the technicians, failure to afford charging/billing price or service requirement by consumers among other factors cause some electrical/electronic products and appliances to be accumulated at technician workshops or stores [25-30]. Onuoha [17] opined that most of electrical/electronic workshops are the house of junks for unrepaired and obsolete equipment. Also, Amachree [31]; Puckett, Westervelt, Gutierrez and Takamiya [32] explained that one quarter of the fairly used electrical/electronic appliances imported to Nigeria are functional, while the remaining three quarter of these appliances are either electronic junk or unserviceable at electrical/electronic workshop. Babatunde [25] argued that these junks of electrical/electronic equipment constitute wastes of Electrical and Electronic Equipment (WasteEEE), which can otherwise be called Electronic Waste (E-Waste) or e-scraps at technicians' workshops. Olaitan, Asogwa and Abu [23] reported that electrical/electronic machines and appliances become e-waste when they are considered out of use for their predetermined purposes.

\section{E-waste}

Kozlan [33] opined that e-waste is all electrical/electronic equipment or products with power plug, and batteries which have become obsolete due to advancement in technology, changes in fashion, style and status, and nearing the end of their useful life. Morgan [34] described e-waste as loosely discarded, surplus, obsolete or broken electrical or electronic devices. Electrical/electronic waste refers to electrical/electronic appliances designed with a voltage rating not exceeding 1000 volts for alternating current and 1500 volts for direct current which have become obsolete, at the end of their lives or that have been discarded by their original users [35-38]. Babatunde [25]; Mundada, Sunil, \& Shekdar, [26]; Ewuim, Akunne, Abajue, Nwankwo \&
Faniran [39]; Eyo [40]; Ogbomo, Obuh \& Ibolo [41] opined that e-waste could be mobile phones, computers, communication equipment, entertainment electronic gadgets, household electronic appliances, audio-visual equipment and other valuable items or less functional and durable electronic gadgets that are no longer in use by their original owners. Scholars submitted that e-waste, in most of the time, is grouped into large household appliances, small household appliances, information technology (IT) and telecommunication equipment and consumer equipment $[38,39,42,43]$. Emphatically, it is very undoubtful to declare that Massive volume and tons of e-waste are produced globally [44]. Specifically, it was estimated by scholars that 20 million to 50 million metric tons of e-waste is generated globally every year [25,45-49]. Thus, United States, Western Europe, China, Japan, and Australia are the major countries holding the leading position on the extent of e-waste generation in the world $[28,50,51]$. Scholars claimed that $50-80 \%$ of waste generated in these industrialized nations are probably exported to developing countries like China, India, Nigeria and Ghana [44,48,49,52-53]. Ogungbuyi, Nnorom, Osibanjo \& Schluep [38]; UN Comtrade [54] estimated that within the year 2006, 2007, 2008, 2009 and 2010, 2794400, 57050, 46750, 2810900 and 403100 tons of electrical/electronic wastes were imported to Nigeria respectively. Eyo [40]; Christine [55]; Obaje [37]; Puckett, Westervelt, Gutierrez \& Takamiya [32]; Sonny [56] reported that 500 containers of fairly used electrical/electronic appliances are imported to Nigeria every months from Europe with each container holding 500 to 800 computers and monitors representing about 400,000 computers arriving to Nigeria every month. Also, Adediran \& Abdulkarim [35]; Amachree [31]; Amanze [57]; Bello, Najib, Umar \& Ibrahim [58]; Basel Action Network, BAN (59); Khurrum, Adnan and Xiaozhe [60]; Nnorom \& Osibanjo [61]; Percy [62]; Puckett, Westervelt, Gutierrez \& Takamiya [32]; Obaje [37] claimed that five million of fairly used personal computers are imported annually into Nigeria through the major sea port of Lagos alone of which $25-75 \%$ of these computer wares are unusable junk and unserviceable. In addition to this, Baldé, Wang, Kuehr \& Huisman [45]; Chimere, Peter, Martina and Willie [47] reported that in 2014, Nigeria generated about 219 kilo tons of e-waste. Meanwhile, Amoyaw-Osei et al. [63]; Edward-Ekpu [64]; Percy [62] reported that 1,100,000 tons of e-waste are generated in each year in Nigeria. Thus, the internally generated e-waste coupled with imported e-waste positioned Nigeria as one of the countries where greater volume of e-waste is generated in Africa and in the world at large.

Ogungbuyi, Nnorom, Osibanjo \& Schluep [38] expressed that the availability of large number of highly trained but low income informal technicians with impressive ability for repairing and refurbishing of used electrical/electronic equipment for local resale has influenced the importation of used electrical and electronic equipment from developed countries like Europe and North America to Africa such as Nigeria. However, following the fact that Nigeria as a nation lacks modern and standardized 
e-waste recycling facility, - the unusable, nonfunctional and unserviceable e-waste is dumped in several public places and sites spread around the cities and country $[39,65]$.

\section{Hazardous Component of E-waste Material}

Analytically, e-waste is made up of certain components like ferrous and non-ferrous metals, and insulators [39]. E-waste items such as battery and Printed circuit boards among others contain primarily metals and non-metals components and most have certain percentage of chromium, lead, copper, nickel, cadmium, and other heavy metals and zinc [26,44,65,66-68]. Scientists affirmed that e-wastes has different hazardous and non- hazardous substances which are broadly consists of ferrous and non-ferrous metals, plastics, glass, wood \& plywood, printed circuit boards, concrete and ceramics, rubber and other items [43]. Heacock, Kelly \& Asante, et al. [44]; Napoleon and Sinclair [68]; Needhidasan, Melvin \& Ramalingam [27] also claimed that e-waste has the content of both toxic and valuable materials in them. Shamsul [69] agreed to this and depicted that most electronic products contain toxic metals of different types which can quickly contaminate the environment when dumped. Thus, electrical/electronic equipment are made from hazardous/toxic elements capable of making e-waste a treat and affecting human and the environmental health in Nigeria [27,32,38,40,60,64,67,69,70-74]. Also, Alake \& Ighalo [75] explained that many components of disposed electrical/electronic waste are heinously toxic, non-biodegradable and ecologically debilitating in nature if accidentally released into the environment. In most of the time, e-waste material has severe negative influence on electrical/electronic technicians and the nearby resident, by affecting the air, water and soil around them [38]. Many studies were conducted on identification of e-waste components but none of these studies was specifically focused on hazardous status of e-waste components based on the quantity of abundance in electrical/electronic technicians' workshops. Thus, part of this study would examine the hazardous status of e-waste components based on the quantity of abundance in electrical/electronic technician's workshop.

These toxins will end up in the biological systems of living organisms causing terminal ailments, diseases and death if allowed [75,76]. Also, Omenogo [28]; Yousif [77] submitted that when e-waste is not properly disposed, the toxic substances present in components of electrical/electronic equipment can be harmful to humans and other organisms. Obaje [37]; Terada [65] claimed that the risk from e-waste affects the entire ecosystems and it is a major environmental health risk to wildlife and humans. For instance, Anwesha \& Pardeep [78] reported that Guiyu in Hong Kong, a flourishing area of illegal e-waste recycling, is battling with shortages of clean and pure water due to the contamination of water resources by e-waste component. Nnorom \& Osibanjo [61]; Sridhar \& Bammeke [79] reported that in an industrialized area of Lagos state, some water body were tested to be acidic with PH scale of 3.40. This was attributed to mobility of heavy metals from disposed e-waste items and ma- terials and from ash and cinder resulting from the open burning process, toward water bodies used for domestic purposes [61]. Also, Obaje [37]; Puckett, Westervelt, Gutierrez \& Takamiya [32]; Terada [65] reported that 4,000 tons of hazardous e-waste (polychlorinated biphenyi) imported to koko area in Delta state, Nigeria from Italy in 1988 caused many people in the area died of cancerous diseases before it was discovered and repatriated back to source country. It is not doubtful to claim that number of studies were carried out on general hazardous effect of e-waste but none of these studies specifically focused on hazardous effect of e-waste in electrical/electronic service workshop. Thus, this study would investigate the possible effect of electrical/ electronic waste components in electrical/electronic workshop to human and its environment.

Pike Research reported that the volume of electronics e-waste, with increasing adoption of electronic gadgets around the world and ever shorter product life cycles, is expected to double over the next 15 years, from 6 million tons in 2010 to 14.9 million tons, by 2025 [55,80-81]. In another submit, Basel Action Network (BAN) claimed that e-waste generated worldwide has elevated from 9.3 million tons in 2005 to 50 million tons in $2012[42,30]$. Thus, the problem is that only around one tenth of these e-wastes were collected and taken care of [42,48,8284 ] while the remaining $90 \%$ become threat to the society and constituting wasting of resources $[44,61]$. In a real sense, collection of electrical and electronic waste is a sustainable process that maximizes recycling to retain valuable e-waste components in the economy and safely disposes of dangerous components [83-84]. Thus, to get rid of these adverse effects of e-waste that are generated in electrical/electronic service workshop, there is need for proper management of e-waste materials.

\section{E-waste management}

Adediran \& Abdulkarim [56] submitted that e-waste management is a process of reducing, reusing and recycling of e-waste. Obaje [37]; Waste Management [85] opined that e-waste management is an effective recovery of all reusable materials from old, nonfunctioning, abandoned and disposed electrical/electronic equipment; and safe disposal of the hazardous substances in them to prevent such toxic material from contaminating the environment. Management of e-wastes involves collection, keeping, treatment and disposal of electrical/electronic waste/ scraps in a safe manner to repudiate/prevent human and its environment from harmful effect e-waste [86,87]. Meanwhile, the practices adopted by electrical/electronic technicians in their workshops to manage e-waste generated seem to be illegal, primitive and unsafe. Anwesha \& Pardeep [78]; Sepúlveda, Schluep \& Renaud [88] claimed that a persistent increase in legal and illegal trade of waste electrical and electronic equipment (WEEE) worldwide has caused equally increasing concern of poor WEEE management techniques. Scholars claimed that unsafe, unregulated and unaccountable collection, processing, and redistribution of old or abandoned electrical/electronic equipment are performed by workers at temporary sites, resi- 
dences, workshops, and open public spaces [44]. Thus, Heacock, Kelly \& Asante, et al. [44]; Solving the E-Waste Problem, StEP, Initiative [89] submitted that general practices of e-waste management among the populaces include using acid baths, burning cables, breaking of e-waste item into smaller parts using forceful approach, and dumping of e-waste materials into an unjustifiable position. Meanwhile, these workers may have embarked on e-waste risky processes and practices due to some challenges they may likely to have been facing such as lack of required knowledge, little or no access to latest technology and personal protective equipment among others $[44,90]$. However, the studies reviewed expatiated on unsafe practices of general public regarding e-waste management and challenges they might be encountered while managing on e-wastes management. Thus, none of these studies empirically claimed the common practices of electrical/electronic technicians regarding e-waste management in Nigeria. One of the focus of this study was to determine the common practice adopted by electrical/electronic technicians to manage e-waste in their workshops and, the challenges which electrical/electronic technicians were encountering over e-waste management in their service workshops.

Azodo, Ogban \& Okpor [88]; Okwesili, Ndukwe \& Nwuzor [91] asserted that management of e-wastes focused on efforts of concerned people through conscious and systematic attempt in maintaining and sustaining an aesthetic, economically viable, physically healthy, conducive and safe environment for living. Hossain, Al-Hamadani \& Rahman [42]; India Central Pollution Control Board [92]; Nnorom \& Osibanjo [61]; Pinto [93] claimed that reclaiming some of the e-wastes materials and recycling them appropriately will mitigate the severe effect of e-waste on living things including plant and animals and their environment. Hossain, Al-Hamadani \& Rahman [42] submitted that proper management of these e-wastes is important for the purpose of getting free from hazardous chemicals effect they possessed. Obaje [37]; Opara [94] claimed also that failure to effectively manage e-waste can leads to adverse environmental deterioration, depletion of potentially valuable resource base for secondary equipment and by extension serves as blocking stone for the attainment of sustainable development.

The goal three and eleven of sustainable development (agenda 2030) declared in September 25-27, 2015 at United Nation Head Quarters, New York emphasized that quality and healthy living and well-being for all at all ages; and inclusive, safe, resilient and sustainable cities and human settlements must be the ultimate priority of all nations including Nigeria [95-103]. The target for attaining these goals among others includes strengthening the capacity of all countries, in particular developing countries, for early warning, risk reduction and management of national and global health risks; and reduces the adverse per capita environmental impact of cities, including paying special attention to air quality and municipal and other waste management [101-102]. However, there is need to device appropriate management techniques for e-waste materials in electrical/elec- tronic workshops globally and in Nigeria to be specific. This will go a long way in helping nations including Nigeria to achieve the sustainable healthy environment which goal three and eleven of agenda 2030 of sustainable development is advocating.

Anwesha \& Pardeep [76] explained that the appropriate management measures of e-waste include establishment of stringent regulations. United Nations Environment Programme, UNEP, [104] opined that strengthening the political cooperation of a country to promote capacity building among workers and enhance public and private investment on safe and environmentally careful waste management technology will reduce adverse effect of e-waste. Also, Alabaster, Asante \& Bergman et al. [105] recognized that bringing poverty to minimum level will alleviate the e-waste challenge in the long-term. Heacock, Kelly \& Asante [44] submitted that raising the awareness and regulation of trans-boundary movement and disposal of hazardous and other wastes is a critical means of managing e-waste. Thus, portion of this study would empirically determine the techniques required to manage e-wastes in electrical/electronic service workshops in Nigeria. This is because none of existing studies has ever investigated on techniques for managing e-waste in technician's workshops. However, the purpose of this study was to advance electrical/electronic waste management techniques among electrical/electronic technicians' workshops for sustainable healthy society. Specifically, the study sort to address the following research questions:

a) What are the hazardous status of e-waste components in electrical/electronic technicians' workshops base on their level of abundance?

b) What are the hazardous effect of e-waste in electrical/ electronic technicians' workshops to human and its environment?

c) What are the common practices adopted by electrical/ electronic technicians to manage e-waste in their workshops?

d) What are the challenges which electrical/electronic technicians encountered over e-waste management in their workshops?

e) What are the e- waste management techniques required in electrical/electronic workshops?

Paul [106] claimed that demographic measures typically are used to identify key respondent characteristics that might influence opinion and/or are correlated with behaviours and experiences. Demographic measures include age, type of school, gender, level of academic study, race and educational attainment among other [106-107]. Thus, this study will test influence of qualification, experience, age and occupation on respondents' opinions on advancement of waste management techniques in electrical/electronic' workshops for sustainable Nigerian health society. 


\section{Hypotheses}

a) HA1 Qualification, experience, age and occupation would significantly influence opinion of engineering lecturers and public health officers on hazardous status of e-waste components base on their level of abundance in electrical/electronic technicians' workshops.

b) HA2 Qualification, experience, age and occupation would significantly influence opinion of engineering lecturers and public health officers on hazardous effect of electrical/electronic waste in electrical/electronic technicians' workshops.

c) HA3 Qualification, experience, age and occupation would significantly influence opinion of engineering lecturers and public health officers on common practices adopted by electrical/electronic technicians to manage e-waste in their workshops.

d) HA4 Qualification, experience, age and occupation would significantly influence opinion of engineering lecturers and public health officers on challenges which electrical/electronic technicians encountered over e-waste management in their workshops.

e) HA2 Qualification, experience, age and occupation would significantly influence opinion of engineering lecturers and public health officers on e- waste management techniques required in electrical/electronic workshops.

\section{Materials and Methods}

The study adopted Descriptive Survey research design. The study was conducted in Nigeria. Nganzi [108]; Gall, Gall \& Borg [109] opined that descriptive surveys research design can be used to collect detailed and factual information that describes an existing phenomenon- their form, actions, changes over time and similarities with other phenomena- from all or a chosen number of the population of the concerned universe. Descriptive survey research design was adopted in this study because information regarding e-waste management was collected from experts using questionnaire. The study sampled one hundred and forty-one participants which included 54 public health officers and 87 engineering lecturers in five Nigerian universities: 20 lecturers from Metallurgical and material engineering, 35 lecturers from Civil engineering and 32 lecturers from Electrical/ electronic engineering in Nigeria. The study adopted structured questionnaire as instrument for data collection. The instrument was divided into Part 1 and 2. Part 1 of the instrument was used to receive demographic information of research participants while Part 2 of the instrument was divided into five sections-A, B, C, D and E- to illicit participant responses on hazardous status of e-waste component, hazardous effect of e-waste components, common practice adopted by electrical/electronic technicians to manage e-waste material, challenges encountered by technicians over e-waste management and e-waste management techniques required in electrical/electronic workshops respectively. Questionnaire items were subjected to face and content validity through the help of three experts from two Nigerian universities. The internal consistency of instrument was checked using Cronbach Alfa method. Thus, 0.76, 0.81, 0.69, 0.85 and 0.70 reliability coefficient estimate were obtained for section A, B, C, D and E respectively. Meanwhile, 0.79 was obtained as reliability coefficient estimate for the overall instrument. The instrument was administered using interpersonal contact by researchers and three research assistants. Researcher ensured consent of research participants using interpersonal discussion before the questionnaire is administered and through consent letter attached to the questionnaire. Data obtained were analyzed using statistical software SPSS 22 . The research questions were answered using mean, standard deviation and percentage. Meanwhile, t-test and analysis of variance (ANOVA) were used to analyze the data at 0.05 level of significance. 50 percent, being the average percentage value, was considered as cutoff point before any item in section A could be considered as strongly belong to any response category.While the average mean value (cut-off point) decision for section B, C, D and E was $\frac{1+2+3+4+5}{2}=3.0$

\section{Presentation of Result}

Table 1 shows detail demographic profile of research participants. Specifically, the table illustrated two group of participants-87 engineering lecturers which comprises of 20 metallurgical and material lecturers, 35 civil engineering lecturers and 32 electrical/electronic lecturers; and 54 public health officers. The participants, in regard to experience distribution, has 9 bachelor's degree holders, 86 master's degree holders and $46 \mathrm{PhD}$ holders. The study participants, regarding experience distribution, comprised six participants with 0-9 years of experience, ninety-nine participants with 10-19 years of experience, nine participants with 20-29 years of experience and twenty-seven participants with 30 and above years of experience. Finally, in regard to age distribution, three of participants fell within the age range of 20-30, eleven participants fell within the age range of 31 and 40, eighty four participants fell within the age range of 41-50, thirty nine participants fell between the age ranges of 5160 and 4 participants fell within the age range of 61-70.

Table 1: Socio-Demographical Profile of the Study Participants $(N=141)$.

\begin{tabular}{|c|c|c|c|}
\hline \multirow{2}{*}{ Demographic Variables } & \multirow{2}{|c|}{ Estimated Value } \\
\hline \multirow{3}{*}{ Qualification } & Demographic Variables & Frequency & \multicolumn{2}{c|}{ Percentage } \\
\cline { 2 - 4 } & BSC/BEng/BTech & 9 & 6.4 \\
\cline { 2 - 4 } & MSC/MEng/MTech & 86 & 61 \\
\cline { 2 - 4 }
\end{tabular}


Insights in Mining Science \& Technology

\begin{tabular}{|c|c|c|c|}
\hline \multirow{4}{*}{ Experience } & $0-9$ & 6 & 4.3 \\
\hline & 19-Oct & 99 & 70.2 \\
\hline & $20-29$ & 9 & 6.4 \\
\hline & 30 and Above & 27 & 19.2 \\
\hline \multirow{5}{*}{ Age } & $20-30$ & 3 & 2.1 \\
\hline & $31-40$ & 11 & 7.8 \\
\hline & $41-50$ & 84 & 59.6 \\
\hline & $51-60$ & 39 & 27.7 \\
\hline & $61-70$ & 4 & 2.8 \\
\hline \multirow{4}{*}{ Occupation } & Public health officers & 54 & 38.3 \\
\hline & Metallurgical and material lecturers & 20 & 14.2 \\
\hline & Civil engineering lecturers & 35 & 24.8 \\
\hline & $\begin{array}{c}\text { Electrical/electronic engineering } \\
\text { Lecturer }\end{array}$ & 32 & 22.7 \\
\hline
\end{tabular}

Data in Table 2 revealed that respondents agreed that all the 34 components of e-waste are hazardous except aluminum. Specifically, lead, mercury, glass and organophosphorus had percentage ratings ranged between $66.6 \%$ and $95 \%$ under the category of 'hazardous when slightly abundant'. This depicted that these components are hazardous and can intoxicate the environment irrespective of the volume and quantity. Iron, copper, wood, yttrium, zinc, chlorobenzene and radioactive elements had percentage ratings ranged between $63.6 \%$ and $90.8 \%$ under the category of 'hazardous when moderately abundant'. This indicated that these components are hazardous but can intoxicate the environment only when they are fairly or averagely abundant. Also, toner dust, cadmium, brominated flame among other components of e-waste had percentage ratings ranged between $61.0 \%$ and $95 \%$ under the category of 'hazardous when largely abundant'. This illustrated that these components are hazardous but can intoxicate the environment only when they are largely or excessively abundant. Meanwhile, aluminum had percentage ratings of $68.8 \%$ under the category of 'not hazardous regardless of state of abundant'. This depicted that aluminum cannot intoxicate the environment regardless of the volume and quantity. Many scholastic reports supported this finding. Reports claimed that over $60 \%$ of the total weight of most of e-waste consists of iron, gold, aluminum, copper, lead, mercury, beryllium, cadmium, chromium and brominated flame retardants, of which $2.7 \%$ are pollutants $[27,110-114]$ and cause severe hazard to ecosystems with the attendant environmental health risk to wildlife and humans $[38,94,115]$. The composition of electronic wastes is mostly in various forms and types, containing more than 1,000 different toxic and non-toxic substances $[42,116]$. Also, gases releases from e-wastes component like polycyclic aromatic hydrocarbons (PAH), brominated flame retardants (BFRs), polychlorinated biphenyls (PCBs) and polychlorinated dibenzo- p-dioxins and furans (PCDD/ Fs) among others affects bio-physical environments and cause detrimental effects to human health [42,117]. Furthermore, scholars reported that some of toxic heavy metals found in e-waste include copper, beryllium, lead, tin, cadmium, brominated flame retardants, antimony, barium, and mercury [25,118]. Obaje [37]; Puckett, Westervelt, Gutierrez \& Takamiya [32]; Terada [65] reported that polychlorinated biphenyl (PCB) exported to Koko area of Delta State, Nigeria in June 1988 was hazardous and caused death of cancer to people of the community.

Table 2: Statistical Analysis of percentage response of university lecturers and public health officers on hazardous status of e-waste components in electrical/electronic technicians' workshops base on the level of abundance $(\mathrm{N}=141)$.

\begin{tabular}{|c|c|c|c|c|c|}
\hline \multirow{2}{*}{ S/N } & \multirow{2}{*}{ E-Waste Component Include: } & \multicolumn{4}{|c|}{ Percentage (\%) Estimate of Response } \\
\cline { 3 - 6 } & & HWSA (\%) & HWMA (\%) & HWLA (\%) & NHRAS (\%) \\
\hline 1 & Toner dust & 17.7 & 5.7 & 75.9 & 0.7 \\
\hline 2 & Lead & 80.9 & 17.7 & 1.4 & 0 \\
\hline 3 & Mercury & 95 & 1.4 & 1.4 & 4.1 \\
\hline 4 & Beryllium & 70.2 & 19.1 & 6.4 & 0 \\
\hline 5 & Cadmium & 12.1 & 5.7 & 82.3 & 70.2 \\
\hline 6 & Brominated flame retardants & 27.7 & 1.4 & & 0.7 \\
\hline 7 & Iron/steel & 21.3 & 63.8 & 2.8 & 12.1 \\
\hline
\end{tabular}




\section{Insights in Mining Science \& Technology}

\begin{tabular}{|c|c|c|c|c|c|}
\hline 8 & Copper & 2.2 & 84.4 & 2.1 & 11.3 \\
\hline 9 & Aluminium & 1.4 & 22 & 7.8 & 68.8 \\
\hline 10 & Glass & 90 & 1.4 & 2.8 & 12.8 \\
\hline 11 & Wood/plywood & 3.1 & 83 & 2.1 & 12.8 \\
\hline 12 & Palladium & 3.5 & 7.1 & 88.7 & 0.7 \\
\hline 13 & Gallium arsenide & 14.9 & 0.7 & 83.7 & 0.7 \\
\hline 14 & Barium compound & 5 & 7.8 & 78 & 9.2 \\
\hline 15 & Asbestors & 28.4 & 2.8 & 58.2 & 10.6 \\
\hline 16 & Chromium & 14.2 & 21.3 & 64.5 & 0 \\
\hline 17 & Nickel & 4.2 & 0.7 & 95 & 0 \\
\hline 18 & Cobalt & 1.4 & 3.5 & 82.3 & 12,8 \\
\hline 19 & Selenium & 2.1 & 2.1 & 83.7 & 12.1 \\
\hline 20 & Tin and organo-tin & 1.4 & 9.2 & 77.3 & 12.1 \\
\hline 21 & Yttrium & 1.4 & 65.8 & 21.3 & 13.5 \\
\hline 22 & Zinc & 0.7 & 64.5 & 22.7 & 12 \\
\hline 23 & Polychlorinated biphenyl & 21.3 & 20.6 & 83 & 0 \\
\hline 24 & Chlorobenzenes & 12 & 84.5 & 3.5 & 0 \\
\hline 25 & polycyclic aromatic hydrocarbons & 5 & 4.3 & 90.8 & 0 \\
\hline 26 & Nonylphenol and nonylphenol ethoxylates & 5.7 & 7.1 & 86.5 & 0.7 \\
\hline 27 & Fluorinated compound & 30.5 & 3.5 & 66 & 0 \\
\hline 28 & Phthalates plasticizer & 24.1 & 2.1 & 73.8 & 0 \\
\hline 29 & Organophosphorus flame & 66.6 & 2.8 & 30.5 & 0 \\
\hline 30 & Phosphorous & 17 & 22 & 61 & 0 \\
\hline 31 & Antimony & 2.8 & 31.9 & 64.5 & 0.7 \\
\hline
\end{tabular}

Table 3 showed that the hazardous effect of e-waste in electrical/electronic workshops stood at mean value of $(4.49 \pm 0.51)$. Meanwhile, the mean rating for each item stood at mean values ranged between $(4.14 \pm 0.35)$ and $(4.63 \pm 0.48)$. This depicted that all the 25 items had mean ratings above the cut-off point of 3.0 and were considered by respondents as hazardous effect of e-waste in electrical/electronic technicians' workshops to human and its environment. United Nations Environment Programme [49] supported this result and herein reported that failure to care for solid wastes including e-waste incurs a severe penalty, later, in the form of resources needlessly lost, foul odours and unsightliness and contamination of air, water, and soil resources. Individuals who live near or on disposal sites, are infected with gastrointestinal parasites, worms, and related organisms [49]. Furthermore, study found that $36.3 \%$ of 1,000 women living near the informal recycling sites experienced stillbirths in the Sylhet region of Bangladesh and $64 \%$ had hearing and/or vision problems [42,119-121]. Also, burnt e-wastes produce smoke, dust or carbon particles from toners consist of carcinogens and other hazardous chemicals which causes severe inflammations and lesions including many respiratory, lung and skin cancer and diseases [68].

Table 3: Statistical Analysis of Mean response of engineering lecturers and public health officers on hazardous effect of electrical/electronic waste in electrical/electronic technicians' workshops to human and its environment $(\mathrm{N}=141)$.

\begin{tabular}{|l|c|c|c|}
\hline & Hazardous Effect of Electrical/Electronic Waste & Mean & Std. Dev. \\
\hline 1 & Contamination of water/ water pollution & 4.63 & 0.48 \\
\hline 2 & Illness on gazing animals & 4.55 & 0.77 \\
\hline 3 & Environmental pollution & 4.6 & 0.49 \\
\hline 4 & Stunted growth among the plants and vegetables & 4.5 & 0.5 \\
\hline 5 & Development of neurological disorder among the people living nearby & 4.62 & 0.49 \\
\hline 6 & Emission of toxic fume, dust and gases to environment & 4.62 & 0.49 \\
\hline 7 & Development of terminal ailment and diseases & 4.44 & 0.77 \\
\hline
\end{tabular}




\section{Insights in Mining Science \& Technology}

\begin{tabular}{|c|c|c|c|}
\hline 8 & Destruction of the soil nutrients & 4.55 & 0.5 \\
\hline 9 & Uncontrolled fire & 4.37 & 0.48 \\
\hline 10 & Long term radiation of hazardous chemicals & 4.55 & 0.5 \\
\hline 11 & Development of respiratory difficulties and pulmonary diseases & 4.55 & 0.51 \\
\hline 12 & Development of lung diseases & 4.57 & 0.51 \\
\hline 13 & Inflammatory problem & 4.58 & 0.49 \\
\hline 14 & Genotoxic effect & 4.61 & 0.5 \\
\hline 15 & Reproductive and estrogenic problem & 4.44 & 0.51 \\
\hline 16 & Exposure to physical risk and injuries & 4.46 & 0.5 \\
\hline 17 & Threat to aquatic animals & 4.38 & 0.49 \\
\hline 18 & Contamination/pollution of soil & 4.6 \\
\hline 19 & Contamination/pollution of air & 4.58 & 0.49 \\
\hline 20 & Skin infection & 4.14 & 0.5 \\
\hline 21 & Cancerous diseases & 4.36 & 0.35 \\
\hline 22 & Asthmatic problem & 4.48 \\
\hline 23 & Blindness & 4.28 & 0.48 \\
\hline 24 & Damage to nervous system & 4.45 & 0.56 \\
\hline 25 & Adverse pregnancy and premature birth. & 4.45 & 0.5 \\
\hline Total & & 4.49 & 0.5 \\
\hline
\end{tabular}

Table 4 showed that the common practices adopted by electrical/electronic technicians to manage e-waste in workshops stood at mean value of $(4.12 \pm 0.61)$. Meanwhile, the mean rating for thirteen items (item 1, 2, 3 4, 5, 6, 7, 8, 9, 10, 11, 13 and 14$)$ stood at mean values ranged between $(3.19 \pm 0.51)$ and $(4.56 \pm 0.50)$. This proclaimed that all thirteen items had mean ratings above the cut-off point of 3.0 and were considered by respondents as common practices adopted by electrical/electronic technicians to manage e-waste in workshops. Meanwhile, item 12 had rating value $(2.34 \pm 0.91)$ bellow the cutoff value of 3.00 and was not considered by respondents as common practices adopted by electrical/electronic technicians to manage e-waste in workshops. The scholars Needhidasan, Melvin \& Ramalingam
[27]; Sivakumaran [68] supported this finding wherein reported that dismantling of e-wastes takes much labor, in countries like China and in some parts of India where big quantity of tons of e-wastes are junked, dismantled, shredding, tearing and burning. Needhidasan, Melvin \& Ramalingam [27]; Sinha-Khetriwal [73] reported that in Mumbai metropolis alone, people throw away 19,000 to 20,000 tons of electronic waste every month. Babatunde [25] reported that uncontrolled burning, disassembly and disposal which are common in the society can cause environmental and health problems. Also, Edward-Ekpu [64] reported that in Nigeria, a lot of e-waste are also stockpiled in offices and homes.

Table 4: Statistical Analysis of Mean response of engineering lecturers and public health officers on common practices adopted by electrical/electronics technicians to manage e-waste in their workshops $(\mathrm{N}=141)$.

\begin{tabular}{|c|c|c|c|}
\hline & Common Practices Adopted by Electrical/Electronics Technicians to Manage E-Waste in their Workshops & Mean & Std. Dev. \\
\hline 1 & Stock piling e-waste or scraps & 4.65 & 0.48 \\
\hline 2 & Burning/incineration e-waste or scraps & 4.43 & 0.8 \\
\hline 3 & Throwing the e-waste/scraps inside heavily flowing water & 4.43 & 0.61 \\
\hline 4 & Dump of e-waste/scraps inside swamp & 4.53 & 0.5 \\
\hline 5 & Use e-waste/scraps as spare part for reinstalling faulty equipment & 4.23 & 0.4 \\
\hline 6 & Selling of e-waste/scraps to recyclers & 4.63 & 0.48 \\
\hline 7 & Bury or use e-waste/scraps to fill the land & 4.46 & 0.5 \\
\hline 8 & Dump e-waste/scraps and with common garbage/waste into the same dustbin & 4.11 & 0.32 \\
\hline 9 & Use of manual processes to recover useful item from e-waste & 3.52 & 1.14 \\
\hline 10 & Handling e-waste/scraps without putting on safety equipment & 4.56 & 0.5 \\
\hline 11 & Heating to circuit board to remove electronics components & 4.3 & 0.46 \\
\hline
\end{tabular}




\section{Insights in Mining Science \& Technology}

\begin{tabular}{|c|c|c|c|}
\hline 12 & Use acid bath to extract metals & 2.34 & 0.91 \\
\hline 13 & Heating of circuit board using coal grills, kerosene burner, propane torches & 3.19 & 0.51 \\
\hline 14 & Shredding and melting/burning metals containing plastic & 4.33 & 0.91 \\
\hline Total & & 4.12 & 0.61 \\
\hline
\end{tabular}

Table 5 showed that the challenges which electrical/electronic technicians encounter over e-waste management stood at mean value of $(4.62 \pm 0.44)$. Meanwhile, the mean rating for each item stood at mean values ranged between $(4.40 \pm 0.49)$ and (4.94 \pm 0.23 ). This depicted that all the 10 items had mean ratings above the cut-off point of 3.0 and were considered by respondents as challenges which electrical/electronic technicians encounter over e-waste management in workshops. Thus, this result was supported by scholars and scientist in the field of waste management. Obaje [37] submitted that e-waste is a major problem in Nigeria today because there is very low level of awareness of the hazards and health risk associated with e-waste. Needhidasan, Melvin \& Ramalingam [27] reported that people who are working with e-waste sector are the urban poor with very low literacy levels and hence have very little awareness regarding the hazards of e-waste toxins. Babatunde [25] reported that one of the challenges facing e-waste management in Nigeria is lack of public awareness by manufacturers and consumers on the inherent dangers of handling and trading in e-waste and lack of a comprehensive e-waste management regulation or legislation in Nigeria to regulate, control and prohibit the flow of used consumer electronic products within Nigeria. E-waste collection in Nigeria is not organized because there are no collection centres for e-waste materials and this however caused most of e-wastes to be dumped along with other wastes [64].

Table 5: Statistical Analysis of Mean response of engineering lecturers and public health officers on challenges which electrical/electronic technicians encounter over e-waste management in their workshops $(\mathrm{N}=141)$.

\begin{tabular}{|c|c|c|c|}
\hline & Challenges which Electrical/Electronic Technicians Encounter Over E-waste Management in their Workshops & Mean & Std. Dev. \\
\hline 1 & Lack of adequate training among electronic technicians on e-waste management. & 4.94 & 0.23 \\
\hline 2 & Lack of adequate information/awareness regarding proper method of handling e-waste/scraps. & 4.63 & 0.48 \\
\hline 3 & Lack of sound regulation and standard concerning e-waste management & 4.97 & 0.19 \\
\hline 4 & Lack of adequate and modern facilities needed to handle e-waste/scraps & 4.62 & 0.49 \\
\hline 5 & Poor technological knowhow among electrical/electronic technicians regarding e-waste/scraps handling. & 4.52 & 0.5 \\
\hline 6 & Lack of knowledge of material components contained by e-waste materials & 4.44 & 0.5 \\
\hline 7 & Lack of technical support from government or other organizations in handling e-waste/scraps. & 4.64 & 0.48 \\
\hline 8 & High cost of transporting e-waste/scraps to recyclers. & 4.55 & 0.5 \\
\hline 9 & Exposure to chemical or equipment injury while handling e-waste/scraps & 4.52 & 0.5 \\
\hline 10 & & 4.4 & 0.49 \\
\hline Total & & 4.62 & 0.44 \\
\hline
\end{tabular}

Table 6 revealed that the e-waste management techniques required in electrical/electronic workshops stood at mean value of ( $4.43 \pm 0.49)$. Meanwhile, the mean rating for each item stood at mean values ranged between $(4.03 \pm 0.58)$ and $(4.96 \pm 0.20)$. This proclaimed that all the 34 items had mean ratings above the cut-off point of 3.0 and were considered by respondents as e-waste management techniques required in electrical/electronic workshops. The reports of past research supported the present findings. Manfred [122] supported this finding and herein reported that waste management service is falling too short of the desired level of efficiency and satisfaction resulting in problems of health, sanitation and environmental degradation due to absence of serious efforts from necessary authorities. Thus,
Needhidasan, Melvin \& Ramalingam [27] reported that technical and policy-level interventions, implementation and capacity building and increasing the public awareness can convert this challenge of massive e-waste generated into an opportunity. Babatunde [25] recommended that government should establish regulatory framework, through relevant agencies to manage e-waste and permanent e-waste collection facilities should be provided at strategic locations and usage of such facilities should be enforced. Ewuim, Akunne, Abajue, Nwankwo \& Faniran [39] submitted that mass education and awareness should be created by regulatory bodies and government on inherent dangers of poor e-waste management on the environment.

Table 6: Statistical Analysis of Mean response of engineering lecturers and public health officers on e-waste management techniques required in electrical/electronic workshops $(\mathrm{N}=141)$.

\begin{tabular}{|c|c|c|c|}
\hline & E-waste Management Techniques required in Electrical/Electronic Workshops & Mean & $\begin{array}{l}\text { Std. } \\
\text { Dev. }\end{array}$ \\
\hline 1 & Provision of information/ awareness on e-waste/scrap management to electrical/electronic technicians & 4.53 & 0.5 \\
\hline
\end{tabular}




\section{Insights in Mining Science \& Technology}

\begin{tabular}{|c|c|c|c|}
\hline 2 & $\begin{array}{l}\text { Encouraging electrical/electronic technicians to follow e-waste standards and regulations and establishing fine for } \\
\text { electrical/electronic technicians who fail to follow the regulation or standard }\end{array}$ & 4.52 & 0.5 \\
\hline 3 & Provision of modern facilities for electrical/electronic technicians for the handling of e-waste/scrap & 4.54 & 0.53 \\
\hline 4 & $\begin{array}{l}\text { Inculcating in electrical/electronic technicians the skills to separate e-waste/scraps component base on their proper- } \\
\text { ties (electrical, thermal, magnetic and density). }\end{array}$ & 4.85 & 0.2 \\
\hline 5 & Provision of capacity building and functional training to electrical/electronic technicians on e-waste/scrap handling. & 4.48 & 0.5 \\
\hline 6 & Availability of functional and effective mechanisms for regular disposal, removal of e-waste/scrap. & 4.16 & 0.37 \\
\hline 7 & $\begin{array}{l}\text { Encouragement of well-trained e-waste collectors and recyclers to be visiting electrical/electronic service workshops } \\
\text { for e-waste/scraps collection. }\end{array}$ & 4.38 & 0.49 \\
\hline 8 & $\begin{array}{l}\text { Availability of cheap transportation to convey e-waste/scraps from electrical/electronic service workshops to recy- } \\
\text { clers or processing site. }\end{array}$ & 4.11 & 0.31 \\
\hline 9 & Availability of separate e-waste collection containers at electrical/electronic service workshops & 4.43 & 0.5 \\
\hline 10 & Establishment of more recycling site and equipment & 4.56 & 0.5 \\
\hline \multicolumn{2}{|r|}{$\begin{array}{l}11 \\
\text { Encourage the importation of new electrical/electronic goods }\end{array}$} & 4.53 & 0.52 \\
\hline 12 & Discourage of importation of used goods to Nigeria & 4.65 & 0.48 \\
\hline 13 & $\begin{array}{l}\text { Provision of e-waste pickers with financial support and useful information regarding the availability of e-waste in } \\
\text { electrical/electronic service workshops }\end{array}$ & 4.28 & 0.97 \\
\hline 14 & $\begin{array}{l}\text { Establishment of standards and regulation guiding the handling and management of e-waste/scraps in electrical/elec- } \\
\text { tronic service workshops }\end{array}$ & 4.17 & 0.93 \\
\hline 15 & Set up functional policy that will monitor and control importation and exportation of electronic equipment & 4.63 & 0.48 \\
\hline 16 & Present, inform of cases to electrical/electronic technicians, the consequences of e-waste primitive management. & 4.39 & 0.49 \\
\hline 17 & $\begin{array}{l}\begin{array}{l}\text { E-waste collected at electrical/electronic service workshops should be processed using environmentally sound equip- } \\
\text { ment. }\end{array}\end{array}$ & 4.38 & 0.49 \\
\hline 18 & $\begin{array}{l}\text { Electrical/electronic manufacturers should be encouraged to be using renewable materials and be discouraged from } \\
\text { using toxic chemicals for their productions. }\end{array}$ & 4.19 & 0.39 \\
\hline 19 & Provision of occupational health guidance to electrical/electronic technicians & 4.3 & 0.46 \\
\hline 20 & $\begin{array}{c}\text { Provision of information to electrical/electronic technicians regarding proper preventive measure against e-waste } \\
\text { health effect. }\end{array}$ & 4.55 & 0.49 \\
\hline 21 & $\begin{array}{l}\text { Encourage electrical/electronic technicians to be using safety equipment while handling electrical/electronic equip- } \\
\text { ment and e-waste items. }\end{array}$ & 4.55 & 0.5 \\
\hline 22 & Selling of e-waste/scraps to recyclers & 4.4 & 0.49 \\
\hline 23 & Encourage electrical/electronic technicians to dump e-waste/scraps to designated container or site & 4.6 & 0.49 \\
\hline 24 & $\begin{array}{l}\text { Encourage electrical/electronic technicians to use e-waste as spare part for the reinstallation of faulty appliances } \\
\text { wherever possible }\end{array}$ & 4.38 & 0.49 \\
\hline 25 & $\begin{array}{l}\text { Encourage the electrical/electronic technicians to send e-waste component (battery or mercury containing compo- } \\
\text { nent) to special recovery facilities }\end{array}$ & 4.62 & 0.49 \\
\hline 26 & $\begin{array}{l}\text { Encourage electrical/electronic technicians to Send hazardous component for destruction in authorized incineration } \\
\text { facilities }\end{array}$ & 4.63 & 0.48 \\
\hline 27 & $\begin{array}{l}\text { Establishment of system for sorting, separating, storing, collection, transportation and disposal of e-waste at electri- } \\
\text { cal/electronic workshop }\end{array}$ & 4.03 & 0.58 \\
\hline 28 & $\begin{array}{l}\text { Organize workshop or seminar for electrical/electronic technicians on proper/save way of handling e-waste: shred- } \\
\text { ding, reshaping, and separation of component base on their characteristics. }\end{array}$ & 4.44 & 0.5 \\
\hline 29 & Given proper recognition to e-waste pickers in the society & 4.33 & 0.47 \\
\hline 30 & $\begin{array}{l}\text { Keep the e-waste pickers and electrical/electronic technicians informed about new technology regarding e-waste } \\
\text { processing }\end{array}$ & 4.2 & 0.4 \\
\hline 31 & Establishing a system that will be monitoring e-waste handling practice at electrical/electronic workshops. & 4.52 & 0.5 \\
\hline 32 & Provision of financial and technical support to electrical/electronic technicians for proper handling of e-waste/scrap & 4.48 & 0.5 \\
\hline 33 & $\begin{array}{l}\text { Provision of proper awareness to electrical/electronic technicians on inherent danger of e-waste poor management on } \\
\text { society. }\end{array}$ & 4.34 & 0.49 \\
\hline 34 & Establishment of e-waste strategic dumping site where further processing can be carried out. & 4.31 & 0.47 \\
\hline Total & & 4.43 & 0.5 \\
\hline
\end{tabular}


Table 7 shows the summary of analysis of t-test and one-way between-groups analysis of variance that was conducted to explore the influence of qualification, experience, age and occupation of public health officers and engineering lecturers on their response to research questions. Participants were divided into three, four, five and two groups according to their qualification, experience, age and occupation respectively.

Table 7: Analysis of statistical influence of engineering lecturers and public health officers' qualification, experience, age and occupation on their response to research questions.

\begin{tabular}{|c|c|c|c|c|c|c|}
\hline \multirow{2}{*}{ Research questions } & \multirow{2}{*}{ Socio-Demographical variables } & \multicolumn{2}{|c|}{ Sum of Square } & \multirow{2}{*}{ Df } & \multirow{2}{*}{$\mathbf{F}$} & \multirow{2}{*}{ Sig. } \\
\hline & & Between & Within & & & \\
\hline \multirow{4}{*}{$\begin{array}{l}\text { What is the hazardous status of } \\
\text { e-waste components in electrical/ } \\
\text { electronic technicians' workshops } \\
\text { base on level of abundance? }\end{array}$} & Qualification & 421.833 & 4352.167 & 2,138 & 6.688 & 0.002 \\
\hline & Experience & 713.051 & 4060.949 & 3,137 & 8.018 & 0 \\
\hline & Age & 1986.4 & 2787.6 & 4,136 & 24.228 & 0 \\
\hline & Occupation & & & $139,90.976$ & $.232^{\mathrm{x}}$ & 0.631 \\
\hline \multirow{4}{*}{$\begin{array}{l}\text { What is the hazardous effect of } \\
\text { e-waste in electrical/electronic } \\
\text { technicians' workshops to human } \\
\text { and its environment? }\end{array}$} & Qualification & 419.17 & 3917.014 & 2,138 & 7.384 & 0.001 \\
\hline & Experience & 876.696 & 3459.488 & 3,137 & 11.573 & 0 \\
\hline & Age & 1086.283 & 3249.901 & 4,136 & 11.365 & 0 \\
\hline & Occupation & & & $139,110.082$ & $.145^{\mathrm{x}}$ & 0.704 \\
\hline \multirow{4}{*}{$\begin{array}{l}\text { What are the common practices } \\
\text { adopted by electrical/electronic } \\
\text { technicians to manage e-waste in } \\
\text { the workshops? }\end{array}$} & Qualification & 166.15 & 20605.013 & 2,138 & 0.556 & 0.575 \\
\hline & Experience & 313.663 & 20457.5 & 3,137 & 0.7 & 0.553 \\
\hline & Age & 548.982 & 20222.181 & 4,136 & 0.923 & 0.453 \\
\hline & Occupation & & & $139,104.969$ & $.627^{x}$ & 0.43 \\
\hline \multirow{4}{*}{$\begin{array}{l}\text { What are the challenges which } \\
\text { electrical/electronic technicians } \\
\text { encounter over e-waste manage- } \\
\text { ment in their workshops? }\end{array}$} & Qualification & 35.122 & 247.062 & 2,138 & 9.809 & 0 \\
\hline & Experience & 1.957 & 280.227 & 3,137 & 0.319 & 0.812 \\
\hline & Age & 35.265 & 246.919 & 4,136 & 4.856 & 0.001 \\
\hline & Occupation & & & $139,113.799$ & $.084^{x}$ & 0.773 \\
\hline \multirow{4}{*}{$\begin{array}{c}\text { What are the e-waste management } \\
\text { techniques required in electrical/ } \\
\text { electronic workshops? }\end{array}$} & Qualification & 1118.941 & 3190.932 & 2,138 & 24.196 & 0 \\
\hline & Experience & 72.44 & 4237.433 & 3,137 & 0.781 & 0.507 \\
\hline & Age & 1488.491 & 2821.382 & 4,136 & 17.938 & 0 \\
\hline & Occupation & & & $139,113.799$ & $.095^{x}$ & 0.759 \\
\hline
\end{tabular}

\section{Hypothesis 1}

Thus, qualification statistically influenced the response of engineering lecturers and public health officers on hazardous status of e-waste components in electrical/electronic workshops base on level of abundance: $F(2,138)=6.688$; Sig. $=0.002$. Experience statistically influenced the response of engineering lecturers and public health officers on hazardous status of e-waste components in electrical/electronic workshops base on level of abundance: $F(3,137)=8.018$; Sig. $=0.000$. Age statistically influenced the response of engineering lecturers and public health officers on hazardous status of e-waste components in electrical/electronic workshops base on level of abundance: $F(4,136)=24.228$; Sig. $=0.000$. Meanwhile, occupation did not statistically influence the response of engineering lecturers and public health officers on hazardous status of e-waste components in electrical/electronic workshops base on level of abundance: $F(139,90.976)=0.232$; Sig. $=0.631$.

\section{Hypothesis 2}

Qualification statistically influenced the response of engineering lecturers and public health officers on hazardous ef- fect of e-waste in electrical/electronic technicians' workshops: $F(2,138)=7.384$; Sig. $=0.001$. Experience statistically influenced the response of engineering lecturers and public health officers on hazardous effect of e-waste in electrical/electronic technicians' workshops: F $(3,137)=11.573$; Sig. $=0.000$. Age statistically influenced the response of engineering lecturers and public health officers on hazardous effect of e-waste in electrical/electronic technicians' workshops: F $(4,136)=11.365$; Sig.= 0.000 . Meanwhile, occupation did not statistically influence the response of engineering lecturers and public health officers on hazardous effect of e-waste in electrical/electronic technicians' workshops: $F(139,110.082)=0.145$; Sig. $=0.704$.

\section{Hypothesis 3}

Qualification did not statistically influence the response of engineering lecturers and public health officers on common practices adopted by electrical/electronic technicians to manage e-waste in the workshops: $F(2,138)=0.556$; Sig.= 0.575. Experience did not statistically influence the response of engineering lecturers and public health officers on common practices adopted by electrical/electronic technicians to manage e-waste 
in the workshops: $F(3,137)=0.700$; Sig. $=0.553$. Age did not statistically influence the response of engineering lecturers and public health officers on common practices adopted by electrical/electronic technicians to manage e-waste in the workshops: $F(4,136)=0.923$; Sig. $=0.453$. Also, occupation did not statistically influence the response of engineering lecturers and public health officers on common practices adopted by electrical/ electronic technicians to manage e-waste in the workshops: $F(139,104.969)=0.627 ;$ Sig. $=0.430$.

\section{Hypothesis 4}

Qualification statistically influenced the response of engineering lecturers and public health officers on challenges which electrical/electronic technicians encounter over e-waste management: $F(2,138)=9.809 ;$ Sig. $=0.000$. Age statistically influenced the response of engineering lecturers and public health officers on challenges which electrical/electronics technicians encounter over e-waste management: $F(4,136)=4.856$; Sig.= 0.001 .Meanwhile, experience did not statistically influence the response of engineering lecturers and public health officers on challenges which electrical/electronic technicians encounter over e-waste management: $F(3,137)=0.319$; Sig. $=0.812$. Also, occupation did not statistically influence the response of engineering lecturers and public health officers on challenges which electrical/electronic technicians encounter over e-waste management: $F(139,113.799)=0.084 ;$ Sig. $=0.773$.

\section{Hypothesis 5}

Qualification statistically influenced the response of engineering lecturers and public health officers on e-waste management techniques required in electrical/electronic workshops: $F(2,138)=24.196$; Sig. $=0.000$. Age statistically influenced the response of engineering lecturers and public health officers on e-waste management techniques required in electrical/electronic workshops: $F(4,136)=17.938$; Sig. $=0.000$. Meanwhile, experience did not statistically influence the response of engineering lecturers and public health officers on e-waste management techniques required in electrical/electronic workshops: $F(3,137)=0.781$; Sig. $=0.507$. Also, occupation did not statistically influence the response of engineering lecturers and public health officers on e-waste management techniques required in electrical/electronic workshops: $F(139,113.799)=0.095$; Sig.= 0.757. Omenogo [28], while comparing the practices of two tertiary institutions in Nigeria on e-waste management, reported that institution was not a determining factor on whether a department keep records of discarded electronic equipment and records of stored out of use electronic items. Ohajinwa, Peter, Martina \& Willie [123] reported also that health risk awareness level of the e-waste workers was significantly lower compared with their counterparts in the same informal sector. Thus, this study has commonalities with those previous studies.

\section{Conclusion}

The study investigated advancement of electrical/electronic waste management techniques among electrical/electron- ic technicians' workshops for sustainable healthy society. The study uncovered the hazardous status of many composition of electronic waste materials based on the level of abundance. The study also revealed empirically the hazardous effect of e-waste materials in electrical/electronic workshops. Also, study confirmed the common e-waste practices among electrical/electronic technicians in their workshops and the challenges they are facing on e-waste management. Finally, this study discovered e-waste management techniques required for managing e-waste materials in electrical/electronic workshops. This study was geared purposely to reconstruct our society for sustainable and conducive living.

\section{Limitation of the study}

The study adopted survey research design wherein questionnaire was used. This was not the best. There was part of this study that required pure and in-depth laboratory investigation. Thus, future study can be centered on this regard.

\section{References}

1. Arthur PMF, Bell DA, Bosworth SG, et al. (1951) The education and training of electrical technicians. Proceedings of the IEE - Part I: General 98(109): 28-37.

2. Hull DM (1986) Introduction: Preparing technicians for tomorrow's jobs. In Technician Education Directory: vii-xvii. Ann Arbor, MI: Prakken Publications.

3. Owen JH (1984) Technician Supply and Demand: How Can Community and Technical Colleges Help Fill the Need? Washington, DC: Council for Occupational Education.

4. Francois C (2005) Computer Technicians: Occupational Outlook Handbook. USA: Graw Hill Publishers.

5. Ibezim NE (2011) Social networking skill needed by technicians of computer hardware maintenance for effective entrepreneurship. Nigeria Vocational Association Journal 16(1): 102-117.

6. Koch JL (1977) Status inconsistency and the technician's work adjustment. Journal of occupational psychology 50: 121-128.

7. Gash DB (1996) The effect of microcomputer on organizational roles and the distribution of power. Unpublished doctoral dissertation Cornell University, New York state school of industrial and labour relations, Ithaca.

8. Stephen RB, Beth AB (1994) In the Backrooms of Science: The Work of Technicians in Science Labs. Work and Occupations 21: 85.

9. Stephen RB (1996) Technicians in the Workplace: Ethnographic Evidence for Bringing Work into Organizational Studies. Administrative Science Quarterly 41(3): 404-441.

10. Seigler CI (1970) Knowledge and skill requirements of consumer electronics service technicians with implications for curriculum development. Retrospective Theses and Dissertations.

11. National Business and Technical Examination Board (NABTEB) (2006) Brochure Guidelines for admission into Federal and State Technical Colleges in Nigeria. Benin. NABTEB.

12. National Board for Technical Education (2001). Installation and Maintenance Work -National Technical Certificate (NTC) and Advanced National Technical Certificate (ANTC)

13. Zambwa J, Makinde AA, Samaila Y (2018) Competency Needs of Radio, Television and Electronics Works Teachers for Effective Teaching in Technical Colleges, Northern States of Nigeria. Multidisplinary Journal of Science, Technology and Vocational Education 6(1): 20-31. 
14. Ohanu IB, Ogbuanya TC (2014) Precautionary Measures Necessary in Liquid Crystal Display (LCD) Television Maintenance by Electronic. Technicians. Modern Economy 5: 201-210.

15. Dearden H (2015) Functional Safety Training for Technicians Measurement and Control 48(10): 307-308.

16. Bureau of Labour Statistics (2010). Electronics \& Electronics Engineers occupational outlook handbook. U.S. department of labour.

17. Onuoha RI (2018) Enhancing Workshop Organizational Technique Adopted by Electronic Technicians in the Informal Sector. European Journal of Education Studies: 4(2): 309-331.

18. Ezeji SCOA (2004) A guide to preparing educational specification for secondary industrial arts facilities. Enugu: cheston agency Ltd.

19. Ofonmbuk IM, Ekereobong SU (2012) School workshop safety practice and students' skill acquisition in electrical installation works in technical colleges in Akwa- Ibom state. Mediterranean Journal of Social Science 3(13): 118-126.

20. Yekinni SA (2015) Prevention and Management of Electrical/ Electronic Workshop. Accidents in Technical Colleges in Oyo and Ogun States, Nigeria (unpublished master's thesis). University of Nigeria, Nsukka, Nigeria.

21. Gazette M (2008) Companies Offering Options on e-waste Disposal.

22. Namias J (2013) The future of electronic waste recycling in the United States: Obstacles and Domestic Solutions (Master of Science Thesis) Columbia University, USA.

23. Olaitan SO, Asogwa VC, Abu M (2013) Technology competencies required by secondary school graduates in maintenance, servicing and repairing of electronic machines for agribusiness occupations to minimize wastage. Journal of Development and Agricultural Economics 5(1): 1-6.

24. Shumeng L (2014) Analysis of Electronic Waste Recycling in the United States and Potential Application in China. (Master of Science Thesis) Columbia University, USA.

25. Babatunde IO (2017) A legal appraisal of the challenges of management of electronic waste in Nigeria. International Journal of Law 3(2): 07-18.

26. Mundada MN, Sunil K, Shekdar AV (2004) E-Waste: A New Challenge for Waste Management in India. Intern. J. Environ. Studies 61(3): 265279.

27. Needhidasan S, Melvin S, Ramalingam C (2014) Electronic waste an emerging threat to the environment of urban India. Journal of Environmental Health Science \& Engineering 12(1): 36.

28. Omenogo M (2014) Institutional E-Waste Management: Comparison of Practices at two Tertiary Institutions in Nigeria. Covenant Journal of Informatics and Communication Technology 2(2): 42-58.

29. Ramachandra TV, Saira VK (2004) Environmentally sound options for e-waste management. Envis Journal of Human Settlements, p. 1-8.

30. Schwarzer S, De-Bono A, Giuliani G, Kluser S, Peduzzi P (2005) E-waste, the hidden side of IT equipment's manufacturing and use. Nairobi, Kenya: United Nations Environment Programme.

31. Amachree M (2013) Update on e-waste management in Nigeria National Environmental Standards and Regulations Enforcement Agency (NESREA), Nigeria presentation at the 3rd Annual Meeting of the Global E-Waste Management Network (GEM3). San Francisco, USA, p. 15-19.

32. Puckett J, Westervelt S, Gutierrez R, Takamiya Y (2005) The digital dump: Exporting re-use and abuse to Africa. The Basel Action Network, Seattle, USA.

33. Kozlan M (2010) What is e-waste and How Can I Get Rid of it? Four Green Steps.
34. Morgan R (2006) Tips and Tricks for Recycling Old Computers

35. Adediran YA, Abdulkarim A (2012) Challenges of Electronic Waste Management in Nigeria. International Journal of Advances in Engineering \& Technology 4(1): 640-648.

36. Benebo NS (2009) Status of e-waste control in Nigeria. NESREA Presentation at the Workshop on E-Waste in West Africa, Accra, Ghana, p. 22.

37. Obaje So (2013) Electronic Waste Scenario in Nigeria: Issues, Problems and Solutions. International Journal of Engineering Science Invention 2(11): 31-36.

38. Ogungbuyi O, Nnorom IC, Osibanjo O, Schluep M (2012) E-Waste Country Assessment Nigeria. E-Waste Africa project of the secretariat of the Basel Convention. Basel Convention Coordinating Centre p. 94.

39. Ewuim SC, Akunne CE, Abajue MC, Nwankwo EN, Faniran OJ (2014) Challenges of E-Waste Pollution to Soil Environments in Nigeria - A Review. Animal Research International 11(2): 1976-1981.

40. Eyo OU (2008) Electronic waste: a growing challenge in Nigeria. Global Journal of pure and applied science 14(1): 459-462.

41. Ogbomo MO, Obuh AO, Ibolo E (2012) Managing ICT waste: The case of Delta State University, Abraka, Nigeria. Library Philosophy and Practice 12(4): 1-9.

42. Hossain MS, Al-Hamadani SMZF, Rahman MT (2015) E-waste: A Challenge for Sustainable Development. Journal of Health \& Pollution $5(9)$.

43. Jalal MDU (2012) Journal and Conference Paper on (Environment) E Waste Management. Journal of Mechanical and Civil Engineering 2(1): 25-45.

44. Heacock M, Kelly CB, Asante KA, Birnbaum LS, Bergman AL, et al. (2016) E-Waste and Harm to Vulnerable Populations: A Growing Global Problem. Environmental Health Perspectives 124(5): 550-555.

45. Baldé CP, Wang F, Kuehr R, Huisman J (2015) The Global E-Waste Monitor 2014: Quantities, Flows and Resources; A Report. United Nations University, UNU-IAS institute for the advanced study sustainability. Bonn, Germany, p. 1-74.

46. Bandyopadyay A (2008) Indian Initiatives on E-waste Management: A Critical Review. Environmental Engineering Science 25(10).

47. Chimere MO, Peter MVB, Martina GV, Willie JGMP (2017) Health Risks Awareness of Electronic Waste Workers in the Informal Sector in Nigeria. International Journal of Environmental Research and Public Health 14(8): e911.

48. Swedish Environmental Protection Agency (2011). Recycling and disposal of electronic waste: Health hazards and environmental impacts. Bromma, Sweden: CM Gruppen AB.

49. United Nation Environmental Program, UNEP (2005). E-waste the hidden side of IT equipment's manufacturing and use. Environment Alert Bulletin 5, January, United Nation Environmental Program, Nairobi, Kenya.

50. Deathe ALB, MacDonald E, Amos W (2008) E-waste management programmes and the promotion of design for the environment: Assessing Canada 's contributions. RECIEL 17(3): 321-336.

51. Monika JK (2010) E-waste management: As a challenge to public health in India. Indian Journal of Community Medicine, 35(3): 382-385.

52. Lundgren K (2012) The Global Impact of e-Waste: Addressing the Challenge. International Labour Office, Programme on Safety and Health at Work and the Environment (Safe Work), Sectoral Activities Department (SECTOR). Geneva: International Labour Office.

53. United Nations Environment Programme, UNDP (2005). Solid Waste Management (Volume I). USA: CalRecovery, Inc. 
54. UN Comtrade (2011) International Merchandise Trade Statistics (IMTS). United Nations Statistics Division.

55. Christine T (2012) Recycling Electronic Wastes in Nigeria: Putting Environmental and Human Rights at Risk. Northwestern Journal of International Human Rights, pp. 154-172.

56. Sonny AA (2005) Red Alert on Used Computers, Electronic Devices. The Guardian.

57. Amanze RE (2013) E-waste economics: a Nigerian perspective: Management of Environmental Quality. An International Journal: 24(2): 199-213.

58. Bello IA, Najib MU, Umar SA, Ibrahim GG (2015) Measurement of natural radioactivity concentration at E-waste dumpsite around Alaba international market Lagos, Nigeria. Advances in Applied Science Research 6(6): 55-64.

59. Basel Action Network (2005). The digital dump: exporting re-use and abuse to Africa.

60. Khurrum MSB, Adnan O, Xiaozhe Y (2011) Electronic waste: a growing concern in today's environment. Economics Research International.

61. Nnorom IC, Osibanjo O (2007) Electronic waste (e-waste): Material flows and management practices in Nigeria. Waste Management 28: 1472-1479.

62. Percy CO (2016) Challenges of Waste Shipments and Inappropriate E-Waste Management in Africa. IMPEL Waste \& TFS Conference: Circular Economy and International Cooperation Eschborn, Germany p. 8-10.

63. Amoyaw-Osei Y, Agyekum 00, Pwamang JA, Mueller E, Fasko R, et al. (2011) Ghana E-Waste Country Assessment: report of component $1 \& 2$ of the UNEP SBC e-waste Africa project for Ghana. Accra, Ghana. Green Advocacy, Ghana \& Empa, Switzerland.

64. Edward-Ekpu DU (2016) Hazardous Waste Management and Challenges in Nigeria. Public Health International 1(1): 1-5.

65. Terada C (2012) Recycling electronic waste in Nigeria: Putting environmental and human rights at risk.NW. J. Int'l Human Rights 10(3): 154.

66. Gibson K, Tierney JK (2006) Electronic Waste Management and Disposal Issues and Alternatives. Environmental Claims Journal 18(4): 321-332.

67. Godwin OI, John IA, Oladele O, Humphrey BO, Micheal OD, et al. (2016) Oxidative Stress and Antioxidant Status in Nigerian E-waste Workers: A Cancer Risk Predictive Study. British Journal of Medicine \& Medical Research 13(2): 1-11.

68. Napoleon OU, Sinclair O (2008) Disposal of e-wastes in Nigeria: an appraisal of regulations and current practices. International Journal of Sustainable Development \& World Ecology 15(6): 565-573.

69. Shamsul C (2016) E-Waste Management to Eliminate Environmental Pollution for the Greater Good. Research in Business and Economics Journal, p. 11.

70. Bhutta KS, Adnam O, Xia OY (2011) Electronic waste: a growing concern in today's environment. Economics Research International.

71. Bridges M (2004) How to set-up and Operate a successful computer refurbishment centre in Africa. Annex M: E waste recycling and implications. Mercury News, NewYork.

72. Culver J (2005) The life cycle of a CPU.

73. Sinha-Khetriwal D (2002) The management of electronic waste: A comparative study on India and Switzerland. St. Gallen, Switzerland: M.S. thesis, University of St. Gallen.

74. Woodell D (2008) Geopedia: e-waste. National geographic.
75. Alake T], Ighalo GI (2012) End of Life Strategies for Effective Electronic Waste Management in Nigeria. International Journal of Scientific \& Technology Research 1(7): 73-76.

76. Institute of Chartered Chemist of Nigeria (2010). The Menace of Electronic Waste. Retrieved from: www. iccn.org.ng.

77. Yousif M (2009) Towards Green ICT (Keynote). ERCIM News, p. 79.

78. Anwesha B, Pardeep S (2012) Electronic waste in India: Problems and policies. International Journal of Environmental Sciences 3(1): 353362.

79. Sridhar MKC, Bammeke AO (1986) Heavy metal contents of some solid wastes in Ibadan, Nigeria. Water, Air and Soil Pollution 29: 51-56.

80. Boggio B, Wheelock C (2009) Executive summary: Electronics recycling and e-waste issues. Pike Research LLC.

81. Mohd FH, Mok KK, Muhamad ZY, Sharifah A. Ahmad MTA, et al. (2016) Investigation of Existing Laptop Computer towards Sustainable Development Using Design for Six Sigma and Design for Disassembly. ARPN Journal of Engineering and Applied Sciences 11(12): 7683-7688.

82. Cobbing M (2008) Toxic tech: not in our backyard, uncovering the hidden flows of e-waste. Full Report, February. The Netherlands: Greenpeace International, Amsterdam.

83. Ladou J, Lovegrove S (2008) Export of Electronics Equipment Waste. International Journal of Occupational and Environmental Health 14(1): 1-10.

84. Saranga A (2014) E-waste free Sri Lanka. Colombo, Sri Lanka: Daily News.

85. Waste Management (2012). What is e-waste management?

86. Attah M (2013) Problems of domestic waste management in Nigeria: any repressors? University of Benin: faculty of law.

87. Azodo AP, Ogban PU, Okpor J (2017) Knowledge and Awareness Implication on E-Waste Management among Nigerian Collegiate. J Appl Sci Environ Manage 21(6): 1035-1040.

88. Sepúlveda A, Schluep M, Renaud FG, Streicher M, Kuehr R, et al. (2010) A review of the environmental fate and effects of hazardous substances released from electrical and electronic equipment during recycling: Examples from China and India. Environmental Impact Assessment Review 30(1): 28-41.

89. Solving the E-Waste Problem Initiative (2011). Annual Report 2011: Five Years of the StEP Initiative. United Nations University/StEP Initiative.

90. Lancet (2013) Electronic waste-time to take stock (Editorial). The Lancet 381(9885): 2223.

91. Okwesili J, Ndukwe C, Nwuzor CI (2016) Urban solid waste management and environmental sustainability in Abakaliki urban, Nigeria European Sci J 12(23): 155-183.

92. India Central Pollution Control Board (2008). Guidelines for environmentally sound management of e-waste.

93. Pinto VN (2008) E-waste hazard: the impending challenge. Indian J Occup Environ Med 12(2): 65-70.

94. Opara S (2013) Experts. The Punch.

95. Brasil (2017) Voluntary National Review on the Sustainable Development Goals.

96. Griggs D, Stafford-Smith M, Gaffney O, Rockström J, Öhman MC (2013). Policy: Sustainable development goals for people and planet. Nature 495(7441): 305-307.

97. Nunes AR, Le K, Riordan OT (2016) The importance of an integrating framework for achieving the Sustainable Development Goals: the example of health and well-being. BMJ Global Health 1: e000068. 
98. Pradhan P, Costa L, Rybski D, Lucht W, Kropp JP (2017) A Systematic Study of Sustainable Development Goal (SDG) Interactions. Earth's Future 5: 1169-1179.

99. Sachs JD (2012) From millennium development goals to sustainable development goals. The Lancet 379(9832): 2206-2211.

100. Stephen M, David P, Neil S (2017) A national global framework for health, development and equity needs a systems approach at every level. British Medical Bulletin, 124: 81-90.

101. United Nations Development Program, UNDP (2017), Sustainable Development Goals.

102. United Nations (2015). Transforming Our World: The 2030 Agenda for Sustainable Development Sustainable development.

103. Yos JU, Ambariyanto A, Muhammad Z, Darsono D, Budi S, et al (2018) Sustainable development goals as the basis of university management towards global competitiveness. Journal of Physics: Conf. Ser 1025.

104. United Nation Environment Programme (2008) Bali Declaration on Waste Management for Human Health and Livelihood. Ninth Meeting of the Conference of the Parties to the Basel Convention on the Control of Transboundary Movements of Hazardous Wastes and their Disposal, Bali, Indonesia p. 23-27.

105. Alabaster G, Asante KA, Bergman A, Birnbaum L, Brune-Drisse MN et al. (2013) The Geneva Declaration on E-waste and Children's Health. WHO Working Meeting on E-waste and Child Health, Geneva, Switzerland.

106. Paul JL (2008) Encyclopedia of Survey Research Methods. California: SAGE Publications, Inc.

107. James LP (1995) A role for demographic variables in the study of absenteeism and turnover. International Journal of Career Management 7(5): 26-32.

108. Nganzi C (2014) Factors influencing secondary school teachers' job satisfaction levels in lang'ata district, Nairobi- Kenya department of education: University of Eldoret. International Journal of Community and Cooperative Studies 1(2): 12-26.

109. Gall MD, Gall JP, Borg WR (2003) Educational research: an introduction. Boston: Omegatype typography, Inc.

110. Bala S, Goel S (2012) A study of e-waste management in relation to awareness of college students. Int J Educ Psychol Res 2: 31-35.

111. Bosshard PP, Bachofen R, Brandl H (1996) Metal Leaching of Fly Ash from Municipal Waste Incineration by Aspergillus niger. Environmental Science and Technology 30(10): 3066-3070.
112. Chen A, Dietrich KN, Huo X, Ho SM (2011) Developmental neurotoxicants in Ewaste: an emerging health concern. Environ Health Perspect 119(4): 431-438.

113. Clark DA, Norris PR (1996) Acidimicrobium ferrooxidans Gen. Nov., Sp. Nov.: mixed-culture ferrous iron oxidation with sulfobacillus species. Microbiology 142: 785-790.

114. Coram NJ, Rawlings DE (2002) Molecular relationship between two groups of Leptospirillum and the finding that Leptospirillum, Ferriphilum Sp. Nov. dominates South African commercial biooxidation tanks which operate at $40^{\circ} \mathrm{C}$. Appl Environ Microbiol 68(2): 838-845.

115. Fowler BA, Weissberg JB (1974) Arsenic poisoning. N Engl J Med 291(22): 1171-1174.

116. Widmer R, Krapf HO, Khetriwal DS, Schnellmann M, Boni H (2015) Global perspectives on e-waste. Environ Impact Assess Rev 25(5): 436-458.

117. Itua E (2013) E-waste dumping in Nigeria: Risk to health and the environment. Nigerian Tribune. Tuesday 5 February.

118. United Nations Environment Programme (2006) Nairobi Conference on Basel Convention to Address the Growing Challenge of Electronic Wastes. Gigiri Nairob Nairobi, Kenya.

119. Wong MH, Wu SC, Deng WJ, Yu XZ, Luo Q, et al. (2007) Export of toxic chemicals- a review of the case of uncontrolled electronic-waste recycling. Environ Pollution 149(2): 131-140.

120. Chowdhury MM, Ahmed AA, Munna GM (2013) Prioritizing e-waste management needs for mitigating hazardous pollutants in NorthEast Zone, Bangladesh. J Appl Technol Environ Sanitation 3(1): 6170.

121. Okorhi J, Amadi-Echendu J, Helen Aderemi H, Otejere J (2015) Technology Paradigm for E-Waste Management in South-Eastern Nigeria. Conference: 24th Annual IAMOT Conference, At the Westin, Cape Town, South Africa.

122. Manfred F (2010) The Threshold Target Approach to Waste Management in Emerging Economies: Pragmatic, Realistic, Appropriate. In E. S. Kumar (Ed.), Waste Management Croatia: In Tech pp.1-16.

123. Ohajinwa CM, Peter MVB, Martina GV, Willie JGMP (2017) Article Health Risks Awareness of Electronic Waste Workers in the Informal Sector in Nigeria. International Journal of Environmental Research and Public Health 14(8): e911.

\section{Your next submission with Juniper Publishers} will reach you the below assets

- Quality Editorial service

- Swift Peer Review

- Reprints availability

- E-prints Service

- Manuscript Podcast for convenient understanding

- Global attainment for your research

- Manuscript accessibility in different formats

(Pdf, E-pub, Full Text, Audio)

- Unceasing customer service

Track the below URL for one-step submission https://juniperpublishers.com/online-submission.php 